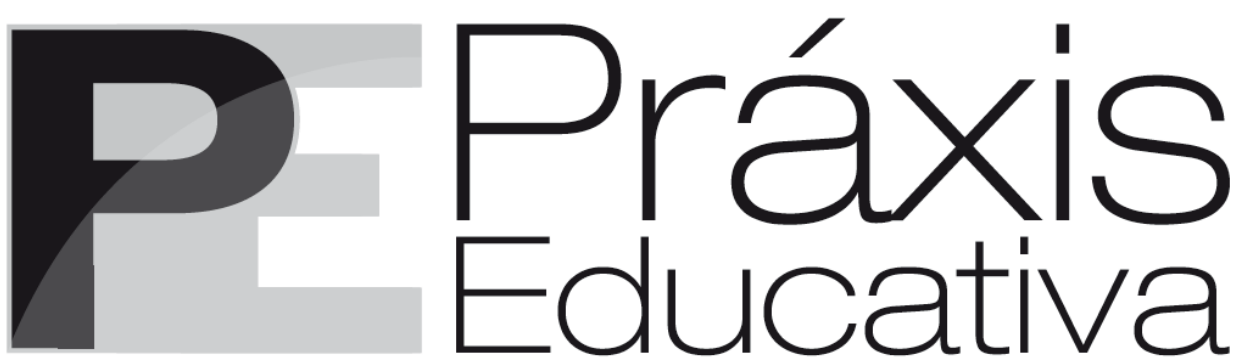

ISSN 1809-4031

elSSN 1809-4309

http://dx.doi.org/10.5212/PraxEduc.v.14n3.009

\title{
Ações educacionais para o idoso nas instituições de Ensino Superior públicas paranaenses*
}

\author{
Educational actions for the elderly in public Higher Education institutions \\ in the state of Paraná
}

\section{Acciones educativas para personas mayores en instituciones públicas de Educación Superior en Paraná}

Paola Andressa Scortegagna*

\begin{abstract}
Resumo: Esta pesquisa é qualitativa, fundamentada a partir da dialética materialista. Objetiva-se analisar as ações educacionais para o idoso desenvolvidas por projetos/cursos nas Instituições de Ensino Superior públicas (IES) paranaenses, como estratégias para emancipação política do idoso, com base na concepção de educação permanente, alicerçada em Konder (2009), Marx (2009), Mészáros (2006) e Oliveira (1998). Para coleta de dados, foram aplicados questionários para 146 idosos das Universidades Abertas para a Terceira Idade (UATI) das IES públicas paranaenses. Foram aplicados também questionários para 25 professores. Como resultados, aponta-se que as ações educacionais para idosos visam processos emancipatórios, embora não apresentem tal denominação em seus objetivos. Mesmo com limitações, a educação para a terceira idade contribui para a sua conscientização, podendo-se vislumbrar a emancipação política a partir da relação dialética entre educação, homem e sociedade.
\end{abstract}

Palavras-chave: Emancipação política. Educação permanente. UATI.

Abstract: This research is qualitative, based on materialist dialectic. The aim is to analyze the educational actions for the elderly developed by projects/courses in public Institutions of Higher Education from Paraná state, Brazil, as strategies for the political emancipation of the elderly, founded on the concept of lifelong education, drawn from Konder (2009), Marx (2009), Mészáros (2006) and Oliveira (1998). For data collection, questionnaires were applied to 146 elderly people of the Open University for the Third Age of the public institutions of Higher Education from Paraná. Questionnaires were also applied to 25 teachers. As a result, the research shows that the educational activities for the elderly aim emancipatory processes, even though they have no such name on their goals. Even with limitations, education for the elderly age contributes to the awareness of the elderly, being able to glimpse political emancipation from the dialectical relationship between education, man and society.

Keywords: Emancipation policy. Permanent Education. Open University for the Third Age.

\footnotetext{
* Artigo oriundo de tese de Doutorado intitulada Emancipação política e educação: ações educacionais para o idoso nas Instituições de Ensino Superior Públicas Paranaenses, orientada pela professora Doutora Rita de Cássia da Silva Oliveira, no Programa de Pós-Graduação em Educação da Universidade Estadual de Ponta Grossa (UEPG).

** Professora da UEPG. Doutora em Educação pela Universidade Estadual de Ponta Grossa. E-mail: paola_scortegagna@hotmail.com. ORCID: https://orcid.org/0000-0002-1243-1989
}

Práxis Educativa, Ponta Grossa, v. 14, n. 3, p. 974-996, set./dez. 2019 Disponível em: < http://www.revistas2.uepg.br/index.php/praxiseducativa> 
Resumen: Esta investigación es cualitativa, fundamentada a partir de la dialéctica materialista. El objetivo es analizar las acciones educativas para la persona mayor desarrolladas por proyectos/cursos en las Instituciones de Enseñanza (IES) públicas de Paraná-Brasil, así comos estrategias para emancipación política de la persona mayor, con base en la concepción de educación permanente, fundamentada en Konder (2009), Marx (2009), Mészáros (2006) y Oliveira (1998). Para la recolección de datos fueron aplicados cuestionarios para 146 ancianos de las Universidades Abiertas para la Tercera Edad (UATI) de las IES públicas paranaenses. Fueron aplicados también cuestionarios para 25 profesores. Como resultados, la investigación apunta que las acciones educativas para personas mayores priorizan procesos emancipatorios, aunque no presenten tal denominación entre sus objetivos. Aún con limitaciones, la educación para la tercera edad contribuye para su conscientización, pudiéndose vislumbrar la emancipación política a partir de la relación dialéctica entre educación, hombre y sociedad.

Palabras clave: Emancipación política. Educación Permanente. UATI.

\section{Introdução}

Ao observar-se a sociedade e a sua forma de organização, há várias questões que emergem, direcionando a uma reflexão em relação à condição de vida dos homens, especialmente como este estabelece relação com os outros, como e qual é seu processo de formação, além das influências da educação, da cultura, do trabalho, da alienação e da ideologia.

$\mathrm{Na}$ sociedade atual, que é capitalista, o processo de marginalização é cíclico, pois, em inúmeras vezes, diferentes grupos sociais são excluídos pela sua condição de vulnerabilidade. Dentre esses grupos, podem-se citar: idosos, crianças, negros, indígenas, homossexuais, entre outros. Em relação aos idosos, estes são considerados em processo de dupla vulnerabilidade, em primeiro lugar, pela questão da idade, e, por conseguinte, por refletirem muitas vezes uma posição de exclusão, de pobreza e de marginalização. Frente aos valores impostos pela classe dominante no sistema capitalista, todos aqueles que são considerados como improdutivos são excluídos.

Diante dessa situação, surge como alternativa a emancipação política, a qual não significa a superação tanto da sociedade de classes quanto da ideologia e da alienação, mas possibilita uma liberdade, mesmo que limitada, que ultrapassa o conformismo diante do sistema vigente. Nesse sentido, considera-se que a educação pode contribuir para que haja acesso aos conhecimentos (social e historicamente acumulados), bem como possibilita que o sujeito alicerce o seu pensamento e a sua ação na cultura, na história, na política e na economia.

Dos grandes grupos de marginalizados, destacam-se os idosos, os quais necessitam de um processo educativo para compreensão (ou, ao menos, melhor discernimento) da sociedade capitalista, sua ideologia e a situação de alienação. No Brasil, atualmente, há cerca de 27,5 milhões de idosos (14\% - IBGE, 2013), os quais representam um grupo quantitativamente significativo, o qual ainda padece com a marginalização e as discriminações. Nesse sentido, a educação permanente tem um papel importante, uma vez que se coloca como um processo contínuo, acompanhando todas as etapas de vida do sujeito.

Em relação aos direitos dos idosos, estes estão garantidos em legislação própria, podendo-se citar o Estatuto do Idoso (Lei $\mathrm{N}^{\circ}$ 10.741, de 1 de outubro de 2003). Sobre a educação, a presente legislação, apresenta nos Artigos 20 ao 25, que o idoso tem o direito à educação garantido, ressaltando a importância de respeitarem-se características próprias da idade. Também se ressalta que o Poder Público deve oportunizar acesso à educação, mediante a oferta 
de cursos para integração à vida moderna, publicações voltadas ao segmento etário, criação de Universidades Abertas para a Terceira Idade (UATI).

Diante dos direitos à educação para o idoso, observa-se que a inserção deles em ações educativas está sendo assumida nas últimas três décadas pelas universidades, por meio de projetos, de programas ou de cursos de extensão. Tais ações são organizadas a partir do princípio da educação permanente, aliada ao papel extensionista das instituições de Ensino Superior. Essas ações podem ser consideradas como significativas, ao propiciar desenvolvimento educacional, articulação com a sociedade, difusão de conhecimentos interdisciplinares e conteúdos para elevar o nível cultural do idoso. Essas ações são organizadas para estimular o idoso, para que este se desenvolva como sujeito, participe da vida social ativamente, perceba o mundo em que está inserido, relacione-se de forma intergeracional, busque atividades diversas e novos papéis sociais.

Assim, esta investigação caracteriza-se como um estudo qualitativo. Em relação aos procedimentos metodológicos, a pesquisa utiliza a dialética materialista (categorias: totalidade, mediação, práxis e contradição). Está fundamentada nos estudos de Oliveira (1998), Mészáros (2006), Konder (2009) e Marx (2009). Tem como objetivo geral: analisar as ações educacionais para o idoso desenvolvidas por projetos/cursos nas Instituições de Ensino Superior (IES) públicas paranaenses como estratégias para emancipação política do idoso, fundamentadas na concepção de educação permanente.

\section{Alienação e emancipação}

A alienação não é uma questão temporária, que será mantida ou superada a partir da organização política ou social. Trata-se de um produto da práxis social, que é constituída no espaço-tempo, e é resultado das relações com os outros, com a família, com o trabalho, com a sociedade e consigo mesmo.

Essas relações elucidam as mais diversas condições históricas e sociais para a conservação da alienação. De acordo com Mészáros (2006, p. 40), a alienação trata-se de um conceito histórico, logo: "Se o homem é alienado, ele deve ser alienado com relação a alguma coisa, como resultado de certas causas - o jogo mútuo dos acontecimentos e circunstâncias em relação ao homem como sujeito dessa alienação - que se manifestam num contexto histórico". Quando se fala da alienação, não se trata de um processo subjacente a toda história da humanidade, trata-se de um fenômeno que emerge a partir da divisão social do trabalho (trabalho manual e intelectual) e do estabelecimento da propriedade privada, pois separa os homens que produzem daqueles que são os detentores dos meios de produção.

Para manutenção de sua sobrevivência, o trabalhador precisa sujeitar-se à venda de sua força de trabalho; assim, não tem mais domínio sobre aquilo que ele produz. Nesse sentido, o homem não produz mais para si, mas para alcançar um determinado objetivo no processo de produção. Logo, a alienação é caracterizada pelo processo de transformação de tudo em mercadoria (até a força de trabalho vai se tornar uma mercadoria), e os trabalhadores são transformados em coisas (coisificação).

Nessa relação subjetiva que se dá entre trabalho e produção, ocorre a desvinculação entre sujeitos e aquilo que produzem, devendo apenas servir como força produtiva. Ainda que a atividade produtiva seja considerada como fonte de consciência e a consciência alienada reflita em uma atividade alienada ou na alienação da atividade (MÉSZÁROS, 2006, p. 80), o sujeito não é resultado exclusivo da alienação por meio do trabalho, mas também da alienação relativa à 
atividade que o antecede, pelos sujeitos presentes em sua formação e a própria reprodução da alienação, que pode acontecer de forma intencional ou não (alienação consciente e inconsciente).

Quando se fala de alienação, não se trata de um processo que se inicia em cada homem, mas de uma ação de reprodução, que progressivamente vai se estendendo com o desenvolvimento do processo produtivo, com as relações políticas, sociais e econômicas. Dessa maneira, independentemente da condição etária, todos os sujeitos estão em uma condição de alienação, não importa sua classe social. Assim, Konder (2009, p. 43) afirma que "[...] a alienação, dentro de uma sociedade dividida em classes, acaba por atingir todos os indivíduos que a compõem, tanto explorados quanto exploradores".

A alienação não se manifesta somente em relações produtivas e na reprodução de conceitos e ideias (ideologia e filosofia), emerge inclusive por meio de relações políticas, econômicas, sociais e até mesmo familiares. Logo, desvela-se uma relação entre os sujeitos que não é mais concreta; entretanto, é dissimulada a partir de uma objetividade ilusória. Nessa perspectiva, o homem não está para si e nem para o outro, uma vez que possui domínio da sua realidade e sofre com a alienação em suas diversas formas (política, ideológica, econômica, religiosa e artística).

Em relação à da sua composição de consciência ideológica, o homem caracteriza-se por não conseguir discernir as relações que estabelece com os outros homens e com a natureza. Não há compreensão da própria experiência, por meio da ação prática que desenvolve enquanto homem e não consegue realizar a apreensão da realidade em que se encontra. Assim, não consegue ver tal processo como prática social, tampouco consegue enxergar-se no cerne da própria ação. Frente às suas limitações, o homem não consegue realizar a síntese da própria atividade e não consegue ter consciência de sua condição de indivíduo, ou seja, como unidade no todo social (KONDER, 2009).

O homem, ao alienar-se ideologicamente, progressivamente perde suas referências, tornando-se domesticado a ponto de crer no que vê como expressão de verdade absoluta e imutável. Assim, a consciência de si está atrelada à experiência daquilo que é vivido, o que representa para a classe operária uma grande limitação, pela restrição ou não acesso à educação, cultura, esporte e lazer.

Historicamente, a alienação surge e é superada. Nesse sentido, o sujeito tem condições de criar sua realidade social, e, por conseguinte, consegue modificá-la. Ao estabelecer novas relações sociais, o homem se desenvolve, como também se diferencia, o que lhe permite a aproximação à compreensão universal, podendo então progredir em maior liberdade, sendo um sujeito considerado mais humano, o qual detém maior domínio das coisas. Isso é a desalienação (GIUDICI, 1973).

Para que o processo de desalienação ocorra, torna-se fundamental a conscientização sobre a alienação, entendendo que esta ocorre de diferentes maneiras. Assim, ao se partir da crítica teórica para atingir a ação prática, reconhecesse a ideologia e toma-se consciência de sua existência. Para tanto, Marx (2008, p. 44) esclarece que: "O modo de produção da vida material condiciona o processo de vida social, política e intelectual. Não é a consciência dos homens que determina seu ser; ao contrário, é o seu ser social que determina sua consciência".

Diante desse cenário, observa-se a necessidade de oportunizar diferentes meios para que os sujeitos da classe dominada tenham verdadeiras condições para que atinjam a tomada de consciência e entendam sua condição de alienados. Além da compreensão da situação de alienação, torna-se basilar atuar em prol da desalienação e buscar meios para a alienação. Para 
tanto, torna-se indispensável, para além da consciência perdida, a consciência da natureza, o estabelecimento de relações dialéticas no plano da realidade (seja material ou ideológica), seguindo para a constituição de um homem consciente, verdadeiramente integrado à ação produtiva e às diferentes condições materiais, essenciais para sua sobrevivência.

Tal processo de conscientização, seja em relação à sociedade ou às condições materiais, não pode estar limitado a uma consciência de uma realidade não limitada, mas sim de uma consciência de sociedade humana. Mészáros (2006) explica que a consciência não ocorre por meio de uma negação a um certo objeto negado, mas por meio de uma positividade. Logo, o autor explica que a única forma para superar a alienação é a partir da ação humana autoconsciente e emancipada, a qual não irá ocorrer por meio de um ato político, filosófico ou econômico, mas irá emergir por meio de situações específicas.

Perante as condições de alienação, o homem perde sua liberdade (no sentido pleno), sendo separada de sua essência material. Esse homem é submetido a algumas pequenas concessões na ordem da participação, da propriedade, da elegibilidade da atividade laboral e inserção social. Logo, emancipar, relaciona-se diretamente à capacidade de recuperar a liberdade. Giudici (1973) explica que se trata de uma libertação do domínio de todas as relações (sejam sociais, políticas, econômicas, culturais) que cercam o homem. Ou seja, mais do que concessão, a emancipação visa a liberdade e a garantia da condição de humanidade do homem.

A emancipação tem por objetivo melhorar a vida dos sujeitos, pois coloca-se como resistência tanto à violência quanto à marginalização; reconhece a identidade do homem e posiciona-se contra todo tipo de opressão. Tendo a práxis como horizonte, a emancipação é desdobrada em dois processos: emancipação política e emancipação humana. A primeira representa a luta para que o homem se torne um cidadão, tendo a considerar sua relação com o Estado e os demais membros sociais. Assim, pode-se afirmar que representa a emancipação da sociedade civil, por meio da concessão de direitos, em relação à política.

Embora seja parcial e com muitas limitações, a emancipação política representa um significativo avanço. Para Marx (2009, p. 52): “A emancipação política é, sem dúvida, um grande progresso; ela não é, decerto, a última forma da emancipação humana, em geral, mas é a última forma da emancipação política no interior da ordem mundial até aqui. Entende-se: nós falamos aqui de emancipação real, de [emancipação] prática”.

A emancipação política busca a junção da força humana com as forças sociais, de forma que o meio político seja considerado um espaço de lutas, com vistas a um objetivo maior que se trata da transformação social. Nesse sentido, as forças sociais representam um expressivo movimento para manutenção da luta por direitos, sendo emancipatória e representando mais do que a mera cessão da garantia de sobrevivência, trata-se da conquista da autonomia. Apesar de um movimento individual, trata-se de libertação e emancipação. Marx (2009, p. 41) aponta que: "Nós temos que nos emancipar a nós próprios primeiro, antes de podermos emancipar os outros".

Nessa condição, a emancipação presume a conscientização. Essa conscientização significa o enfrentamento e o entendimento das condições contraditórias, as quais são reflexos do capitalismo e difundidas pela classe opressora. $\mathrm{O}$ ato de conscientizar-se pressupõe identificar a necessidade do enfrentamento social e também político a fim de atender às demandas fundamentais para a sobrevivência do homem. Tal processo não se restringe apenas à luta contra o sistema, mas para superar a alienação, levando em consideração a capacidade deste homem em lutar contra a sua alienação e a alienação do outro.

Práxis Educativa, Ponta Grossa, v. 14, n. 3, p. 974-996, set./dez. 2019 Disponível em: <http://www.revistas2.uepg.br/index.php/praxiseducativa $>$ 
Emancipação é sinônimo de libertação de algo ou de alguma condição em que o homem ou seu coletivo se encontram (ou seja, da alienação). Dessa maneira, somente há demanda de emancipação quando uma determinada situação é propícia para superação de limitações já existentes. Assim, tanto ideologia quanto alienação são criações da humanidade. Uma sociedade que é determinada ideologicamente a partir de uma classe dominante e que aliena foi historicamente determinada. Nesse sentido, toda superação pressupõe uma ação humana, a qual é condicionada pela conscientização.

Tal cenário não é restrito a uma consequência inevitável da humanidade, muito menos se trata de uma utopia que não se alcança. Assim, a emancipação humana não é reflexo de uma sociedade imaginária ou de uma finalidade inconcretizável. Não presume um tipo de sociedade totalitária ou supressão das diferenças e da individualidade dos sujeitos. Trata-se de uma forma de sociedade na qual o trabalho associado (supera o trabalho alienado) permita que o homem seja protagonista da sua vida e do seu destino (TONET, 2013).

Nessa acepção, pensando em uma perspectiva emancipatória, a educação tem o papel de contribuir para orientar a superação de relações políticas parcializadas, além de contribuir para a emancipação política, e atuar, se possível, em direção à emancipação humana, em sua totalidade. Todavia, importante salientar que a emancipação humana não ocorre apenas por meio da educação, pois esta trata-se apenas de uma das instâncias sociais.

\section{Educação}

A educação é um processo que possibilita a automediação do homem, em busca de sua autorrealização. Trata-se de uma ação exclusivamente humana, pessoal e interna, pois nenhum sujeito é educado sem a sua aceitação e sua participação. Dessa forma, esse processo deve priorizar para que a autoeducação seja desenvolvida no sujeito, visando superar a exterioridade na totalidade, sem que haja estagnação, mas, sim, um processo contínuo (MÉSZÁROS, 2006). Logo, a educação é considerada como parte da totalidade e atua para o desenvolvimento do homem, para que este atinja a universalidade.

Em relação ao processo emancipatório, a educação é fundamental, desde que possua como objetivo principal a formação humana de forma integral, em que considera a relação do homem com o outro e com a natureza, sua relação e interação com o trabalho, sua condição enquanto sujeito e todo seu processo de humanização.

Quando se estabelece os princípios de uma educação que se volta à emancipação, esta precisa ser essencialmente crítica, indo além da mera aquisição de conhecimentos acumulados. Nesse sentido, por meio de um processo dialético, o homem deve obter condições para compreender as relações que se estabelecem entre realidade e pensamento. A educação precisa objetivar a formação para a realidade e não para a alienação (AMBROSINI, 2012).

Segundo Pinto (2010), a educação trata-se de um processo, pois expressa a formação do sujeito no transcorrer do tempo, caracterizando-se como um fato histórico. Pode ser considerada como um fato existencial, pois está relacionada a maneira de como o homem se faz homem. É, também, fato social, ao fazer referência à sociedade e a forma como esta se reproduz, primeiro como um ato de incorporação, que visa a manutenção da sociedade, mas também como progresso, uma vez que objetiva o avanço, como uma alternativa de ruptura das estruturas estabelecidas, além da formação da autoconsciência.

Práxis Educativa, Ponta Grossa, v. 14, n. 3, p. 974-996, set./dez. 2019 Disponível em: < http://www.revistas2.uepg.br/index.php/praxiseducativa > 
A educação pode ser considerada como concreta, pois esta precisa de condições objetivas para ocorrer. Concomitantemente, ela é exponencial, uma vez que representa a necessidade da ação contínua, ou seja, quanto mais se educa, mais se é preciso educar. No entanto, a educação possui uma natureza contraditória, pois, ao mesmo tempo que busca a manutenção da conservação, ela promove a criação, seja por meio da crítica, da negação ou da substituição do conhecimento (PINTO, 2010).

Nessa lógica, a educação é marcada pela contradição, seja por meio das suas características ou nos diferentes espaços em que é desenvolvida. Logo, a mesma ação educativa que pode ser alienante é a mesma que possui subsídios passáveis para buscar a desalienação do homem, considerando-se aqui todo movimento dialético a que a educação é subjacente e as relações estabelecidas com os determinantes sociais, como a política, a economia e a cultura.

Mais do que uma questão individual, a educação atua para que o sujeito, sendo consciente de si, possua subsídios suficientes para a inserção social, com perceptibilidade do que é a sociedade e como esta está organizada. Dessa forma, a educação precisa ser conduzida pela conscientização e não pela mera reprodução. O homem precisa, então, entender e conhecer o que significa a sua humanidade e como esta se transpõe na sociedade, o que representa a continuidade possível de sua existência. Assim, a educação é a ação sobre a consciência do homem (TONET, 2013).

Ao considerar o caráter social que a educação possui, entende-se que o sujeito não se limita em sua existência, mas que possua condições de participação e de transformação, mesmo que esta seja simples, limitada e pouco aprofundada. Mészáros (2008) explica que, para que ocorra uma participação ativa e o processo de integração social, o homem precisa ter consciência da ação que realiza e entender qual é a sua importância e a sua contribuição para o contexto coletivo.

A consolidação da práxis educativa não irá se encerrar apenas em espaços educativos escolares formais, mas se estende a toda ação educativa, onde quer que ela se desenvolva, tendo a formação do homem integral como sua principal finalidade. A educação colabora para que seja recriada a continuidade histórica, não como mera repetição sistêmica, mas como processo dialético, que se pauta na possibilidade de continuidade da mudança (MÉSZÁROS, 2006).

Perante a infinitude do processo educativo e da natureza inacabada do homem, fortalecese a condição de continuidade por meio de uma educação que seja permanente. Freire (2007, p. 27-8) explica que: "A educação é uma resposta da finitude da infinitude. A educação é possível para o homem, porque este é inacabado e sabe-se inacabado". Considerando o sujeito como ser inacabado, é fundamental que haja uma formação no decorrer de toda sua existência, de forma contínua.

A educação permanente, assim, possui grande importância, esforçando-se em afirmar o imperativo da propagação dos espaços educativos para além da escola, considerando a relevância das ações provenientes da educação não formal.

A ideia de totalidade é a que melhor exprime o ponto de partida da educação permanente, à medida em que focaliza o homem em toda sua dimensão, imerso na sua problemática existencial, onde os aspectos biológicos e sociais são importantes, e a própria história de vida individual. Ao mesmo tempo, a educação permanente é a que melhor responde a essa necessidade de uma educação para a mudança, exigindo pessoas que se integrem ativa e criativamente, para melhor responderem aos desafios que nem sempre podem ser equacionados. A educação é práxis, na qual a interação homem/situação é muito mais dinâmica e real, acentuando as modificações do ambiente que se refletem no homem e vice-versa. (OLIVEIRA, 1998, p. 243).

Práxis Educativa, Ponta Grossa, v. 14, n. 3, p. 974-996, set./dez. 2019 Disponível em: <http://www.revistas2.uepg.br/index.php/praxiseducativa> 
A educação permanente avança a perspectiva individual e, em seu sentido de totalidade, assinala que não é somente o homem que tem uma formação voltada à universalidade, porém busca expandir a sociedade para a solidariedade humana, em que haja objetivos comuns de vida e de melhoria das condições sociais. Por meio dela, o sujeito vai adquirindo conhecimentos e capacidade de realizar reflexões, para que consiga desenvolver sua capacidade de entender a vida (na totalidade de sua humanidade).

No processo de educação permanente, considerando suas características, pode-se destacar o idoso que, como segmento etário, representa uma parcela significativa da população, a qual, ao longo das décadas, vivenciou limitações de escolarização, diferentes reorganizações e conjunturas do mercado de trabalho, alterações demográficas e sociais, diferentes configurações políticas, além de direito negados e diversas rupturas econômicas e culturais.

\section{Idoso}

Compreender quem é o idoso no Brasil permite a ampliação da discussão acerca dos processos históricos, políticos, econômicos e culturais que fazem parte de sua formação. Não apenas um grupo etário, os indivíduos idosos refletem a marginalização e a discriminação do sistema capitalista, que valoriza o novo, o útil e o lucrativo.

Os idosos, pessoas com 60 anos ou mais (Estatuto do Idoso - Lei $\mathrm{N}^{\circ}$ 10.741, de 1 de outubro de 2003), são um grupo etário com uma população em torno de 27,5 milhões de pessoas, os quais representam $14 \%$ da população brasileira (IBGE, 2013). Mesmo com uma grande quantidade de idosos, essa realidade não deve ser apenas sinônimo de uma constatação. É fundamental que diferentes ações, como na política, na economia, na saúde, na educação e na cultura, sejam tomadas para que esse segmento etário não seja mero elemento estatístico, mas um grupo importante que não pode estar simplesmente alienado, marginalizado e vulnerabilizado. Para tanto, a implementação de políticas voltadas ao idoso são fundamentais, mas sem entendêlas como um caráter redentor, que tem o poder de erradicar todos os problemas, mas como uma alternativa que possa contribuir para a efetivação de ações específicas para a terceira idade.

Quando se pensa em política para o idoso, não se trata de uma benfeitoria do Estado, mas, sim, de um longo processo de discussão, de disputa e de negociação até a sua implementação (considerando suas limitações). Nesse sentido, Fernandes (1997, p. 22-23) afirma que: "Por políticas de velhice entende-se o conjunto de intervenções públicas, ou ações colectivas, que estruturam, de forma explícita ou implícita, as relações entre a velhice e a sociedade".

Mesmo que os condicionantes do capitalismo estejam impregnados nos atos do Estado e que a base hegemônica esteja voltada à acumulação do capital em detrimento da exclusão, do preconceito e da desigualdade, as políticas públicas direcionadas ao idoso demonstram uma possibilidade, mesmo que limitada, de propiciar condições de vida e sobrevivência a uma parcela da população que durante sua trajetória de vida sofreu com a degradação social e econômica.

Em relação aos direitos do idoso, na legislação brasileira, há três documentos representativos, por sua especificidade: Constituição Brasileira (1988), Política Nacional do Idoso (1994) e Estatuto do Idoso (2003). De acordo com a Constituição Federal, que trata da consolidação do Estado Democrático de Direito no Brasil, no Art. 5': "Todos são iguais perante a lei, sem distinção de qualquer natureza, garantindo-se aos brasileiros e aos estrangeiros residentes no País a inviolabilidade do direito à vida, à liberdade, à igualdade, à segurança e à propriedade" (BRASIL, 1988, p. 5). Ainda, na Constituição, há a prescrição de direitos e de 
garantias fundamentais que são distribuídos em: direitos e deveres individuais e coletivos; direitos sociais; nacionalidade; direitos políticos. Nesse contexto, o idoso, sendo considerado um cidadão, tem direito de usufruir de todos os direitos que estão garantidos na Constituição, mesmo que seja indicado apenas em três artigos.

Apesar da Constituição Federal representar um avanço significativo no que diz respeito aos direitos da população idosa, há grandes problemas sobre a efetividade desses direitos. Assim, mesmo com a prescrição de direitos fundamentais, estes estão muito distantes do contexto social de vida do idoso e não correspondem a um processo de emancipação, tampouco atendem às demandas emergentes. Assim, diante da necessidade de atendimento das demandas do idoso, aliada à pressão popular, a partir de diversas reivindicações oriundas de grupos diversos de terceira idade e da própria sociedade, no ano de 1994, houve a sanção da Lei $\mathrm{N}^{\circ}$ 8.842, de 4 de janeiro de 1994, que dispõe sobre a Política Nacional do Idoso, que é a primeira legislação brasileira específica para esse segmento etário.

No artigo $1^{\circ}$ da referida lei, prescreve-se que: “A política nacional do idoso tem por objetivo assegurar os direitos sociais do idoso, criando condições para promover sua autonomia, integração e participação efetiva na sociedade" (BRASIL, 1994, n.p.). Além disso, a Lei N ${ }^{\circ}$ 8.842/1994 determina direitos indispensáveis para o idoso, dentre os quais citam-se: cidadania, participação, respeito, trabalho, capacitação, previdência, assistência social, habitação, não discriminação, atualização, educação, saúde, cultura, esporte e lazer.

Apesar do avanço no que diz respeito à criação dessa lei, houve pouca efetividade. A Política Nacional do Idoso foi pouco conhecida e difundida, e a população idosa continuou marginalizada e distanciada de seus direitos fundamentais. No ano de 2003, após um amplo debate e ações da sociedade civil, foi promulgada uma nova lei, já mencionada anteriormente, para os idosos no Brasil: o Estatuto do Idoso, Lei $\mathrm{N}^{\circ}$ 10.741/2003. O Estatuto do Idoso apresentou redação muito semelhante à da Política Nacional do Idoso, dando-lhe um caráter de revisão e não de originalidade. Embora as duas legislações brasileiras para o idoso sejam semelhantes em diversos aspectos, a Lei $\mathrm{N}^{\circ}$ 10.741/2003 não revogou a Lei $\mathrm{N}^{0}$ 8.842/1994. Assim, como a Política Nacional do Idoso, o Estatuto do Idoso prescreve os direitos fundamentais da população idosa. Entretanto, diferentemente do que aconteceu com a Política Nacional do Idoso, o Estatuto do idoso foi amplamente divulgado pelas diversas mídias, representando uma ação governamental em defesa do segmento etário.

Incontestavelmente, o Estatuto do Idoso representou e ainda representa um importante avanço para a população idosa. Entretanto, ao idoso, mais do que conhecer a existência de uma legislação, é necessário que identifique e entenda que os diferentes direitos prescritos nessa lei são seus, os quais precisam ser implementados na materialidade de diferentes ações e não como um plano ideal ou como mera propaganda governamental.

Para o idoso, conhecer seus direitos contribui para transformações, pois permite entender e denunciar situações de preconceito, vulnerabilidade e marginalização, como também compreender o que lhe é garantido, contribuindo para mais dignidade e melhores condições de sobrevivência. 


\section{O idoso e o seu direito à educação}

A educação, além de processo que é ideológico, dialético, contraditório, e transformador, como já dito anteriormente, também é um direito, historicamente construído e garantido. Ao considerar-se o Estado Democrático de Direito, todo sujeito tem direito à educação; logo, o idoso também possui este direito. Mesmo se tratando de um direito fundamental, a educação nem sempre foi e é de acesso ao idoso, o que representa a contradição entre o que está prescrito e o que é concreto. Para além desse ponto, não há legislação brasileira específica sobre a educação do idoso, tampouco há na legislação educacional prescrições sobre o processo educativo na terceira idade.

A Constituição Federal prescreve, no Artigo 205, que a educação é um direito de todos e dever do Estado e da família (BRASIL, 1988). Assim, entende-se que, ao tratar-se de um direito de todos, inclui-se o idoso. Na Lei de Diretrizes e Bases da Educação Nacional, Lei No 9.394 , de 20 de dezembro de 1996, não há qualquer menção para o idoso, apenas menciona-se que uma das modalidades da educação é a Educação de Jovens e Adultos (EJA). Nas Diretrizes Curriculares Nacionais para a Educação de Jovens e Adultos, o idoso é citado dentro da modalidade, considerando-o na categoria adultos, entretanto sem quaisquer menções sobre as especificidades e as peculiaridades do processo educativo dessa população, como adaptação de metodologias e materiais.

Sobre as legislações específicas para o idoso, há prescrições relevantes para a educação. A Política Nacional do Idoso apresenta, no Artigo $4^{\circ}$, as Diretrizes, destacando-se dentre elas: "VII - estabelecimento de mecanismos que favoreçam a divulgação de informações de caráter educativo sobre os aspectos biopsicossociais do envelhecimento" (BRASIL, 1994, n.p.). Sobre o processo educativo, no Capítulo IV (Das Ações Governamentais), Artigo 10 (competências dos órgãos e entidades públicos), Parágrafo III, apontam-se: adequação de currículos, metodologias e materiais didáticos; inserção de conteúdos voltados ao processo de envelhecimento nos currículos do ensino formal; informações para a população sobre o processo de envelhecimento; apoiar a criação das UATI (BRASIL, 1994).

O Estatuto do Idoso também prescreve o direito à educação. No Artigo $3^{\circ}$, destaca-se, entre outros direitos, que a educação deve ser assegurada com prioridade ao idoso, seja pela família, comunidade, sociedade e Poder Público (BRASIL, 2003). O Estatuto apresenta, no Capítulo V, algumas prescrições específicas à educação, contemplando também a cultura, o esporte e o lazer. Entre os Artigos 20 e 25, embora com muitas semelhanças à Política Nacional do Idoso, há destaque para a educação, com determinações sobre o direito do idoso à educação, adequações curriculares, cursos para integração à vida moderna, inclusão de conteúdos sobre o envelhecimento nos níveis do ensino formal, incentivo de publicações adequadas ao segmento e a criação das UATI (BRASIL, 2003). Quando se fala em educação, trata-se de um importante direito a ser assegurado ao idoso. Assim, a educação permanente tem um papel fundamental, pois propicia ao sujeito o conhecimento, como também um incentivo para a conscientização, o que poderá possibilitar que o idoso entenda a sua alienação e possa atuar para a sua emancipação.

As ações voltadas à população idosa são relevantes, pois possibilitam integração e melhor compreensão sobre o processo de envelhecimento. Dentre tais ações, podem-se destacar aquelas voltadas à educação, como as UATI, as quais são baseadas nos princípios da educação permanente, não pautadas apenas em ocupação do tempo livre, mas buscam promover mudanças para que o idoso seja mais consciente do seu próprio processo de envelhecimento e entenda que a idade não é um limitador de atividades e de expectativas.

Práxis Educativa, Ponta Grossa, v. 14, n. 3, p. 974-996, set./dez. 2019 Disponível em: <http://www.revistas2.uepg.br/index.php/praxiseducativa $>$ 
Ações educacionais para o idoso nas instituições de Ensino Superior públicas paranaenses

\section{Universidades Abertas para a Terceira Idade: ação educacional para o idoso}

As Universidades Abertas para a Terceira Idade (UATI) são consideradas como ações extensionistas e têm um papel significativo na atuação das universidades no que diz respeito às questões referentes à velhice e ao envelhecimento. Mesmo não sendo a única ação extensionista que atua junto ao público idoso, pois existem outras atividades nas instituições de Ensino Superior, as UATI têm grande representatividade, uma vez que, ao longo das últimas três décadas, foram adquirindo reconhecimento social pelo desenvolvimento de diversas atividades, as quais contemplam o envelhecimento e a velhice nos seus diferentes aspectos: psicológicos, biológicos e sociais.

As Universidades Abertas para a Terceira Idade no Brasil estão organizadas a partir da realidade local de cada instituição, conferindo-lhes um caráter de semelhança entre os diferentes programas/projetos, mas salvaguardando particularidades específicas. Tais especificidades vão além de nomenclatura ou sigla (Universidade Aberta para a Terceira Idade, Universidade da Terceira Idade, Universidade Aberta para Maturidade). Há também diferenças sobre a organização curricular, que pode ocorrer por meio de disciplinas ou de módulos, como atividades de cunho artístico e cultural, além da quantidade de alunos por turma, tempo de duração de cada disciplina ou módulo, dentre outros.

As UATI também são diferentes quanto à sua modalidade de extensão, pois há programas, projetos e cursos. Essa diversidade é reflexo das concepções sobre velhice e envelhecimento existentes nas universidades, como também se refere à área de vinculação de ações extensionistas (educação, saúde, educação física, psicologia, ciências sociais), como também da ausência de uma política específica que subsidie os coordenadores para a estruturação, a organização e o funcionamento das UATI.

Sobre o critério de ingresso dos alunos idosos, embora haja pequenas diferenças entre as UATI, podem-se indicar: ser idoso (60 anos ou mais), com cotas para pessoas com 55 anos ou mais; ser alfabetizado (com comprovação legal ou autodeclaração); aceitar as regras e organização da UATI. Não há processos seletivos ou classificatórios. Ocorrem matrículas em determinados períodos (anual ou semestral), geralmente por ordem de chegada, obedecendo a quantidade de vagas disponibilizadas. Há lista de espera (quando necessário).

Sobre as atividades que as UATI desenvolvem, não se restringem à ocupação de tempo livre, mas voltam-se ao desenvolvimento do idoso, o qual, quando instrumentado com diferentes conhecimentos, terá condições de conhecer e de melhor entender o processo de envelhecimento, além da possibilidade de ocupação com atividades que possibilitam ao idoso relacionar experiência individual com a sociedade em que está inserido.

As UATI, no sentido educativo, realizam uma ação pedagógica voltada para que o idoso conheça suas limitações e suas capacidades, bem como desenvolva-se para constituir-se como sujeito. Promove novas oportunidades, para que o idoso consiga reconhecer e posicionar-se frente aos preconceitos socialmente construídos sobre a velhice e o envelhecimento. Tais ações não contribuem apenas para a melhoria da qualidade de vida, mas buscam maior inserção social do idoso, preocupando-se em atender às demandas desse segmento (CACHIONI et al., 2015).

Quando se pensa na ação educativa das UATI, observa-se que muitas vezes esta busca atuar em uma perspectiva de educação emancipatória, compreendendo que o idoso é um sujeito marginalizado, além de rotulado por inúmeros estereótipos negativos relativos às diversas incapacidades, as quais não comprovadas cientificamente, mas oriundas de uma construção cultural (OLIVEIRA, 1999). Nessa perspectiva de educação, o idoso é colocado no centro do 
processo, para que, por meio da aquisição de conhecimentos, perceba-se como um sujeito que é capaz e socialmente integrado, o qual irá estabelecer relações com o outro e com a sociedade.

Considerando a amplitude das ações e dos objetivos das UATI, pode-se considerar que essas ações extensionistas possuem: caráter educacional, caráter social e caráter político.

1. Caráter educacional: baseado nas premissas da educação permanente. Opera de forma com que o idoso obtenha diferentes conhecimentos e que, além da atualização, reconheça e entenda quais são seus direitos, atingindo uma maior consciência sobre si e sobre sua participação na sociedade. Contribui de forma com que o idoso expanda seus conhecimentos nas áreas em que possua interesse e amplie seu aparato cultural. Esse caráter atua também na colocação do idoso como protagonista no processo educativo, possibilitando ao indivíduo a realização de estudos, de pesquisas e de leituras, não mantendo-o somente na condição de receptivo de informações ou conhecimentos. Reafirma que o estereótipo da incapacidade de aprender é equivocado, pois mesmo o aluno idoso expondo um ritmo de estudo ou interesses diferenciados não é impossibilitado de fazer parte do processo de aprendizagem. Nesse sentido, é imprescindível a qualificação de professores para atuarem com alunos idosos, bem como o desenvolvimento de materiais e metodologias adequadas.

2. Caráter social: é atingido por meio da contribuição das UATI para que o idoso conheça seus direitos, mas também esteja conscientizado para atuar em prol da sua concretização, por meio de implementação de políticas e de ações do governo em suas diferentes esferas. Juntamente ao caráter educacional, o caráter social irá contribuir para que o idoso não se mantenha em um isolamento, estabelecido social e culturalmente por meio de mecanismos sociais e ideológicos, os quais dão à população idosa uma condição de peso social e reafirmam que o idoso possui incapacidade para o trabalho, economia, lazer, cultura, relações pessoais e sociais. Assim, as UATI contribuem para que o idoso tome consciência do espaço social que ocupa e da sua condição de alienação, e, instrumentalizado com os meios oferecidos, compreenda a importância de emancipar-se e lute por isso. Dessa maneira, objetiva-se que os idosos que frequentam as UATI tenham melhorias na sua qualidade de vida, integrem a sociedade, participem ativamente, ampliem o seu convívio social, assumam novos papéis sociais, mantenham e ampliem as suas relações intergeracionais tanto na família quanto fora dela, como também possuam o sentimento de valorização e de resgate de sua dignidade.

3. Caráter político: para além de atendimento de uma prescrição legal presente no Estatuto do Idoso - Art. 25, Parágrafo único: “O poder público apoiará a criação de universidade aberta para as pessoas idosas [...]” (BRASIL, 2003, n.p.) -, essas ações, diante de sua natureza e pelas atividades que desenvolvem, podem ser consideradas como políticas públicas, as quais são dirigidas para a instância pública tanto da população idosa como do restante da população, que clama por condições melhores para o envelhecimento. Não se trata de uma mera ação de política assistencialista, muito menos compensatória, uma vez que seus objetivos não estão limitados ao atendimento de fragilidades, mas voltam-se à superação da visão liberal de envelhecimento, em que se considera o idoso como um peso social. Como uma política, a UATI pode assumir-se como política social, por sua forma de humanização, além de reconhecer a natureza humana e social do idoso, como também o processo de envelhecimento e de velhice. Assim, caráter político da UATI está voltado a atuar junto ao idoso, em uma alternativa para a conscientização e, por conseguinte, buscar a emancipação política, superando toda e qualquer forma de alienação.

Apesar de não se considerar as especificidades de cada UATI, apresentando-se uma discussão ampliada, a partir dos pontos apresentados, é possível afirmar que suas ações extensionistas e educacionais têm limitações diversas, como a quantidade de alunos que conseguem atender, reconhecimento da instituição de Ensino Superior (ou não), os tipos de 
atividades oferecidas aos idosos, aceitação ou resistência por parte dos idosos, dificuldades oriundas do governo e do próprio sistema capitalista, ausência de financiamento público para execução das ações (várias UATI precisam ser autônomas - autogerir recursos). Entretanto, apesar das diversas dificuldades enfrentadas, essas ações buscam desenvolver a potencialidade do segmento, seja nos contextos político, econômico, social, cultural e educacional.

Assim, conhecer as Universidades Abertas para a Terceira Idade irá possibilitar entender quem são os alunos idosos que as frequentam e quais são os motivos que os levam a ingressar em uma atividade dessa natureza. Permite, também, conhecer sobre sua organização e seus fundamentos e, na qualidade de processo educativo, como pode contribuir para o processo de emancipação política do sujeito idoso.

\section{Ações educacionais para o idoso: as UATI contribuem para a emancipação política?}

As instituições de Ensino Superior públicas paranaenses, quando oferecem ações como a UATI, trazem as discussões sobre o idoso para o debate institucional, como também incluem o idoso em espaços universitários, por meio dessas ações, as quais contribuem para uma ressignificação das práticas sociais e culturais. Esse movimento de trazer o idoso para a universidade contribui significativamente para o processo de conscientização do idoso frente aos preconceitos e às marginalizações vigentes.

Assim sendo, esta pesquisa apresenta uma relação entre o idoso, a educação e a emancipação política, considerando a realidade política, econômica, social e cultural, como também a historicidade que permeia essa realidade. A investigação ampara-se na dialética materialista, ao considerar que o envelhecimento está relacionado diretamente ao movimento (do real aparente para a busca do real concreto, por meio da síntese). De acordo com Konder (2012, p. 36): "A síntese é a visão de conjunto que permite ao homem descobrir a estrutura significativa da realidade com que se defronta, numa situação dada. E é essa estrutura significativa - que a visão de conjunto proporciona - que é chamada totalidade".

O idoso, sujeito da sua própria história, em um tempo e espaço demarcados, estabelece diferentes relações por constituir-se um ser social, que está intrinsecamente ligado ao contexto social, político e cultural, no qual, quando e se emancipado, pode agir, interagir e modificar a história. Esta pesquisa busca a apreensão da velhice, como um fenômeno, e da problemática apresentada em consonância com o contexto macro. Para Konder (2012), o conhecimento é totalizante e a atividade humana, na maioria das vezes, trata-se de um processo de totalização, que nunca irá alcançar uma etapa acabada e definitiva. Assim, a visão de conjunto é sempre provisória e não pode ter a pretensão de esgotar a realidade a que faz referência.

\section{Apresentação dos dados}

Para execução do processo investigativo, foi realizada uma pesquisa de campo com idosos e professores das UATI das instituições de Ensino Superior paranaenses (Universidade Estadual de Ponta Grossa; Universidade Estadual do Paraná (Paranaguá); Universidade Estadual do Centro-Oeste (Irati; Guarapuava); Universidade Estadual do Oeste do Paraná (Foz do Iguaçu); Universidade Estadual de Maringá; Universidade Federal do Paraná).

Foram elaborados dois questionários, ambos com questões abertas e fechadas: 1. Para os idosos contendo questões sobre perfil, educação e política; 2. Para professores, com questões sobre perfil, educação e a UATI. Os questionários foram aplicados para os professores e idosos 
nas instituições, com autorização prévia e agendamento da coordenação de cada ação extensionista. Para aplicação dos questionários, houve processo de esclarecimento sobre os objetivos e problema de pesquisa; além disso, a autora realizou a apresentação e elucidou as dúvidas sobre o instrumento e o Termo de Consentimento Livre e Esclarecido. Antecedendo a coleta de dados, todos os sujeitos foram informados sobre o anonimato e a confidencialidade dos dados e que estes somente poderiam ser utilizados na pesquisa a partir do consentimento dos participantes. Após todos os esclarecimentos e orientações, ocorreu o processo de coleta de dados, em primeiro lugar com os idosos, em local e data determinado pela coordenação. Em seguida, ocorreu a coleta de dados com os professores, todos em espaço distinto dos idosos. Em todas as instituições, realizou-se o mesmo procedimento de coleta de dados. Esse processo de esclarecimentos diz respeito aos procedimentos éticos para realização da pesquisa, respeitando a singularidade dos sujeitos de pesquisa e de acordo com a metodologia elegida a partir do objetivo geral e da questão problematizadora.

Os dados dos questionários estão separados por público: aluno e professor, enumerados de acordo com a instituição (Exemplo: aluno da instituição 1 - 1A01; professor da instituição 2 2P01).

Alunos

O questionário para os idosos das UATI teve como objetivo conhecer o perfil dos alunos, bem como a relação que estabelecem com a educação e a política. Nas sete UATI das IES públicas paranaenses, 146 idosos responderam ao questionário.

As primeiras questões dizem respeito ao perfil dos alunos. Sobre a idade dos partícipes, 81 idosos têm entre 60 e 69 anos, o que corresponde a 55,47\%; 38 idosos têm entre 70 e 79 anos (26,02\%); entre 50 e 59 anos, há 15 pessoas (10,27\%). Outros 12 idosos têm idade entre 80 e 89 anos, correspondendo a $8,21 \%$.

A segunda questão diz respeito ao gênero. Pode-se observar a predominância do sexo feminino, com 123 alunas mulheres (84,24\%), enquanto há 23 alunos homens (15,75\%). Sobre estado civil: há 59 casados (40,41\%) e 60 viúvos (41,09\%). Há 15 pessoas separadas $(10,27 \%)$, sete são solteiras $(4,79 \%)$ e cinco pessoas não definiram seu estado civil $(3,46 \%)$.

Relativo à escolaridade, 45 têm o Ensino Médio completo (30,82\%). Há 31 pessoas com Ensino Superior, 21,23\%. Outras 21 pessoas possuem Pós-Graduação (14,38\%). Em relação ao Ensino Fundamental, 20 pessoas têm completo (13,69\%) e 18 pessoas, incompleto $(12,32 \%)$. Também há 11 pessoas com o Ensino Médio incompleto (7,53\%).

Em relação à renda familiar: 34 pessoas têm renda familiar mensal maior do que cinco salários mínimos (23,28\%); 32 pessoas com renda entre dois e três salários (21,91\%); 22 idosos têm renda de até um salário $(15,06 \%) ; 21$ pessoas com renda entre três e quatro salários $(14,38)$; 19 idosos com renda entre um e dois salários (13,01\%); 18 pessoas com renda entre quatro e cinco salários $(12,32 \%)$.

Sobre a moradia: a maioria dos idosos vive em casa própria (132 pessoas), o que corresponde a $89,72 \%$. Os demais vivem em casa alugada (oito pessoas - 5,47\%) e casa cedida (sete pessoas - 4,79\%). Nessas moradias, 71 idosos (48,63\%) moram com seu(s) filho(s); 61 idosos (41,78\%) vivem com companheiro; 36 idosos vivem sozinhos $(24,65 \%) ; 11$ (7,53\%) vivem com seu(s) neto(s); quatro idosos vivem com outro (2,73\%); dois idosos moram com um amigo 
(1,36\%). Dentre os idosos, 122 têm filhos, o que representa 83,56\% (dois filhos: 37 pessoas 25,34\%; três filhos: 43 pessoas - 29,45\%; quatro filhos ou mais: 42 pessoas $-28,76 \%$ ).

Os idosos também foram questionados sobre educação e política, entendendo que o processo de compreensão sobre o envelhecimento e a velhice depende do conhecimento e das vivências que o sujeito adquire ao longo de sua vida, bem como as condições objetivas e subjetivas que possui para chegar à conscientização.

As questões referentes à educação estão diretamente relacionadas à ação extensionista em que o idoso está matriculado. A primeira questão é relativa ao tempo que frequenta a UATI. Dos participantes desta pesquisa, 61 pessoas estão em uma das UATI entre 1 e 3 anos, contabilizando $41,78 \%$. Outras 30 pessoas estão na UATI entre 4 e 6 anos, o que corresponde a 20,54\%. Há ainda 26 pessoas que frequentam as UATI há 10 anos ou mais (17,80\%). Com menos de 1 ano de frequência, há 22 pessoas $(15,06 \%)$. Também há sete pessoas que estão frequentando as UATI entre 7 e 9 anos $(4,79 \%)$.

A próxima questão é relativa aos motivos que levaram o idoso a entrar na Universidade Aberta para a Terceira Idade. Nessa questão, também era possível assinalar mais de uma alternativa. Para 110 pessoas, entrar na UATI é para a melhoria da qualidade de vida (75,34\%). Para 95 idosos, um dos motivos é a vontade de aprender mais $(65,06 \%)$. Conhecer pessoas novas motivou 86 pessoas (58,90\%). Há, ainda, 52 que apontam para a indicação de amigos $(35,61 \%)$. Aqueles que queriam nova ocupação equivalem a 35,61\% (52 pessoas). Apenas cinco pessoas indicam que seu ingresso na UATI está relacionado à imposição de familiares (3,42\%).

Outra questão é relativa às mudanças ocorridas após o ingresso na UATI. Dentre as respostas dos alunos, destacam-se: conhecer novas pessoas, para 115 idosos (78,76\%); capacidade de aprender mais, para 106 idosos (72,60\%); maior realização (pessoal), para 91 idosos $(62,32 \%)$; realizar atividades diversificadas, para 83 idosos (56,84\%); sentir-se útil, para 73 idosos $(50,00 \%)$; superar o sentimento de solidão, para 39 idosos $(26,71 \%)$.

Os idosos também foram questionados sobre a atuação dos professores das UATI. Para 135 alunos das ações extensionistas, os professores são atenciosos e pacientes (92,46\%). Também apontam que os professores fazem explicações claras (89 pessoas - 60,95\%). Há 82 idosos que indicam que os professores se preocupam com a aprendizagem dos alunos (56,16\%). Para 67 idosos, os professores utilizam materiais adequados (45,89\%).

É importante também salientar que muitos idosos consideram os professores atenciosos e pacientes $(92,46 \%)$, o que indica que a relação que se estabelece entre eles é positiva, e que, nesse quesito, os professores estão atendendo às demandas desse segmento.

Os alunos também foram questionados sobre o que mais gostam na UATI. Nessa questão, também tinham a opção de marcar mais de uma opção. Os idosos indicaram que mais gostam de: colegas (95 pessoas - 65,06\%); aulas (90 pessoas - 61,64\%); possibilidade de aprender ( 90 pessoas - 61,64\%); professores ( 85 pessoas - 58,21\%); atividades recreativas/festas (75 pessoas $-51,36 \%$ ). Outros 15 idosos indicaram nomes de disciplinas.

Outra questão é referente àquilo que os idosos gostariam que mudasse na UATI. A maioria dos idosos não apontou necessidade de mudança na UATI (72 pessoas - 49,31\%). Em relação às mudanças, a inclusão de novas atividades foi indicada por 50 idosos $(34,24 \%)$. Também foram indicadas mudanças no espaço físico (20 pessoas - 13,69\%), horários das atividades $(13-8,09 \%)$ e professores (quatro pessoas - 2,73\%). Havia a alternativa "outros",

Práxis Educativa, Ponta Grossa, v. 14, n. 3, p. 974-996, set./dez. 2019 Disponível em: < http://www.revistas2.uepg.br/index.php/praxiseducativa > 
assinalada por 38 pessoas (26,02\%), que indicaram inclusão de atividades específicas, ampliação do número de vagas e da duração do curso.

Em relação à saúde e à qualidade de vida, os idosos foram questionados sobre como se sentem após o ingresso na UATI. Nessa questão, também havia opção de assinalar mais de uma alternativa. De acordo com os resultados, 86 idosos se sentem com mais empolgação e vontade de viver após ingressar na UATI $(58,90 \%)$. Há 81 idosos que se sentem com mais autonomia $(55,47 \%)$, outros 80 idosos se sentem com mais disposição para realização de atividades cotidianas (54,79\%), 69 idosos têm mais ânimo para planejar suas atividades e desejo de realizálas $(47,26 \%), 65$ idosos se sentem com vontade de realizar atividades diversas em casa e na universidade (44,52\%), 43 idosos se sentem com disposição para acordar $(29,45 \%)$.

Os idosos também foram questionados sobre políticas relacionadas ao cotidiano, sua relação com seus direitos e a atuação das UATI nesse aspecto. Dessa forma, foram questionados se conhecem o Estatuto do Idoso, Lei No 10.741/2003. Dos idosos, 98 apontam que conhecem o Estatuto $(67,12 \%)$ e 48 dizem que não o conhecem (32,87\%).

Após essa questão, foi solicitado que os idosos indicassem quais são as principais contribuições do Estatuto do Idoso. Os 98 idosos elencaram direitos prescritos no Estatuto, como o sujeito 1A4, que indicou: "Atendimento preferencial e imediato juntos aos órgãos públicos e privados. Fornecimento gratuito de medicamentos de uso contínuo. Descontos de $50 \%$ em várias atividades de lazer e culturais. Gratuidade no transporte coletivo público". O idoso 1A16 aponta que as contribuições do Estatuto: "Assegura ao idoso a vida, alimentação, educação, cultura, saúde, esporte, lazer, trabalho, cidadania, liberdade, dignidade, respeito e convivência à família e comunitária". Outros 82 sujeitos indicam direitos relativos à saúde, à segurança, à previdência, ao trabalho, à educação, à cultura, à moradia e à participação social. Destaca-se também que, dentre estes, 13 apontam para a necessidade de conhecer os direitos e entender melhor o Estatuto.

Os idosos também foram questionados se a cidade em que residem tem Conselho Municipal do Idoso. De acordo com os dados, 96 idosos sabem que há o Conselho em sua cidade $(65,75 \%)$. Outros dois idosos apontam que não há, provavelmente por desconhecimento. Entretanto, cabe destacar que 35 idosos não sabem se há ou não há o Conselho, que é um espaço político e representativo, voltado à defesa dos direitos do idoso.

Os idosos também foram questionados se participam de algum conselho ou entidade que defende os direitos do idoso. A maioria aponta que nunca participou (109 pessoas $-74,65 \%)$. Entretanto, há 25 idosos que indicam que não participam neste momento, mas que já participaram $(17,12 \%)$. Outros 12 idosos afirmam que participam $(8,12 \%)$.

Os idosos foram questionados sobre qual é a situação social do idoso no Brasil. De acordo com os dados, para 91 pessoas, a situação volta-se à dificuldade de acesso à saúde (62,23\%), 74 apontam para problemas econômicos (50,68\%), 68 indicam a discriminação e a marginalização (46,57\%) e 64 apontam para a violência (43,83\%), indicando a situação do idoso a partir das questões negativas. Para 45 pessoas, a situação é de reconhecimento e valorização $(30,82 \%)$. Há nove pessoas $(6,16 \%)$ que indicaram outras respostas, como dificuldades para realização de atividades cotidianas e participação em grupos sociais.

A próxima questão é voltada à indicação de qual é a maior fragilidade da terceira idade. Os idosos puderam indicar mais de uma alternativa. Dentre as fragilidades, destacaram-se: saúde para 98 pessoas $(67,12 \%)$; preconceito para 69 pessoas $(47,26 \%)$; aposentadoria para 67 pessoas 
(45,89\%); transporte e família, ambos para 42 pessoas (28,76\%); moradia para 25 pessoas $(17,12 \%)$; e educação para 21 pessoas (14,38\%).

A próxima questão versava se o posicionamento político do idoso mudou após o ingresso na Universidade Aberta para a Terceira Idade. Para 26 pessoas, o posicionamento político não mudou (17,80\%). Para 99 pessoas, o posicionamento político mudou após o ingresso na UATI $(67,80 \%)$. Desses sujeitos: nove pessoas apontam que têm mais conhecimentos sobre a condição do idoso e dos direitos; oito pessoas afirmam que se sentem mais integrados à terceira idade; seis apontam que ampliou a capacidade de discussão sobre a velhice em seus aspectos sociais, políticos e culturais; seis idosos se sentem mais valorizados/melhores; cinco pessoas explicam que têm condições de reivindicar seus direitos; quatro se sentem mais conscientes.

A última pergunta referia-se à educação contribuir para o reconhecimento social do idoso. Para 126 pessoas, a educação contribui de diferentes maneiras para o reconhecimento social da terceira idade (86,30\%). De acordo com o idoso 1A16: “A aprendizagem é um processo permanente de construção. Inicia-se ao nascer e prolonga-se por todas as etapas da vida. Traz melhorias se o idoso se integrar às técnicas de comunicação, computação e demais avanços tecnológicos da vida moderna. O analfabeto continua marginalizado". Como explica o sujeito 6A7, a educação: "Contribui porque um povo educado é um povo conscientizado daquilo que quer e isso nos traz melhorias para o cotidiano de nossas vidas".

Em destaque às três últimas questões sobre o posicionamento político, as contribuições da educação e o reconhecimento social do idoso, evidencia-se a importância das ações extensionistas educacionais das IES públicas paranaenses, bem como o papel da educação na terceira idade. Não se tem a pretensão de afirmar que a educação irá equacionar os problemas sociais da velhice, mas ela atua como um meio para que o idoso adquira mais conhecimento sobre si, sobre o processo de envelhecimento e tenha condições de entender melhor o contexto social em que está inserido, para que possa identificar quais são os seus direitos e como poderá atuar em prol da melhoria das suas condições de sobrevivência.

\section{Professores}

O questionário para os professores das UATI foi organizado em duas partes, a primeira sobre o perfil e a segunda sobre questões pedagógicas. Houve a participação de 25 professores, que não foram separados por instituição, para apresentação dos dados. No que diz respeito ao perfil desses professores, a primeira questão era relativa à idade. Dos 25 professores, nove têm idade entre 50 e 59 anos (36\%). Há cinco com idade entre 20 e 29 anos (20\%), quatro com idade entre 60 e 69 anos (16\%), três com idade entre 40 e 49 anos (12\%), dois professores com idade entre 70 e 79 anos (8\%) e outros dois com idade entre 30 e 39 anos (8\%).

Em relação ao gênero, há 13 professoras (52\%) e 12 professores (48\%). No que diz respeito à formação, há 10 com Doutorado (40\%), seis com Ensino Superior (24\%), quatro com Especialização (16\%), quatro com Mestrado (16\%) e um com Ensino Médio (4\%).

Os professores também foram questionados sobre o tempo que atuam na UATI. Há 10 professores que atuam entre 1 e 3 anos na ação extensionista (40\%), oito professores atuam entre 4 e 6 anos (32\%), quatro professores atuam entre 7 e 9 anos $(16 \%)$, dois professores estão a menos de 1 ano (8\%) e um professor está há mais de 10 anos na UATI (4\%). 
Sobre as atividades em que atuam, pode-se observar que os professores trabalham com disciplinas/oficinas em diversas áreas. Dos professores que participaram da pesquisa, quatro atuam com Atividades Físicas (16\%), quatro trabalham com atividades na área da Psicologia $(16 \%)$, outros quatro trabalham com Línguas Estrangeiras $(16 \%)$. Há três professores que trabalham com atividades na área das Artes, o que representa 12\%. Para atividades de Informática, Geografia, Matemática e Saúde, há dois professores em cada uma das áreas (8\%). Há um professor que atua na disciplina de Inserção Comunitária (4\%) e outro que atua com Resgate da Memória (4\%).

Sobre as questões pedagógicas, os professores foram questionados se possuíam alguma formação específica para atuar com o público idoso. Dos participantes, 21 indicaram que não têm formação específica (84\%), e apenas quatro registraram que possuem formação (16\%). Destes quatro professores, um possui Especialização em Inclusão Educacional, um tem formação pela Pastoral da Pessoa Idosa, um tem cursos na área (casa asilar) e um possui formação na área da Psicologia.

Os docentes foram questionados sobre as principais dificuldades ao trabalhar com idosos. De acordo com 11 professores, a maior dificuldade está nos poucos materiais voltados ao segmento (44\%). Para 10 professores, a limitação do trabalho com os idosos está nas dificuldades de aprendizagem (40\%), sete professores apontaram as dificuldades em relação à heterogeneidade dos alunos $(28 \%)$ e outros sete indicaram a questão da adaptação de metodologias (28\%). Dos sete que assinalaram a opção "Outras", quatro apontaram para o problema da assiduidade dos alunos e três professores indicaram que não sentem dificuldades para trabalhar.

O grupo dos docentes foi questionado sobre a participação dos idosos nas atividades (disciplina/oficinas). Para 22 docentes, os idosos são muito participativos (88\%), dentre estes professores, 16 também afirmam que os idosos são comunicativos e apontam suas dúvidas e dificuldades (64\%). Para dois professores, os idosos são concentrados e interessados, mas não questionam ou fazem apontamentos $(8 \%)$.

A próxima questão versava sobre como o professor se sente ao trabalhar com o idoso. Há 19 professores que indicaram que se sentem satisfeitos (76\%) e outros 15 professores se sentem realizados profissionalmente $(60 \%)$. De acordo com o professor 3P4, a justificativa dá-se: "Porque estamos incluindo num contexto global essas pessoas que, ao longo das suas vidas, não tiveram oportunidades de ter um aprendizado e porque elas abraçam a nossa proposta de trabalho e, mesmo diante das dificuldades da vida presente, elas aceitam e superam os desafios".

Sobre esse posicionamento, emerge um dos critérios de ingresso, que é o idoso ser alfabetizado. Logo, reflete o fato de que muitos idosos não tiveram oportunidade de escolarização ao longo de suas vidas ou a tiveram parcialmente (embora na pesquisa há uma quantidade significativa "possui Ensino Médio (30,82\%)", a coleta de dados não foi realizada com todos os idosos matriculados). Nesse sentido, observa-se que, mesmo diante de possíveis dificuldades de ordem metodológica, os professores se sentem satisfeitos e realizados com o trabalho que realizam com os idosos.

Os docentes também foram questionados se atuam em outros espaços profissionais. Há 19 que atuam em outros espaços $(76 \%)$ e seis que atuam somente nas UATI (24\%). Desses 19 professores, seis apontam que se pudessem atuariam apenas com idosos. Todos os professores concordam que a UATI contribui para que o idoso seja mais participativo no seu grupo de convivência e na sociedade (25 professores - 100\%).

Práxis Educativa, Ponta Grossa, v. 14, n. 3, p. 974-996, set./dez. 2019 Disponível em: <http://www.revistas2.uepg.br/index.php/praxiseducativa> 
Sobre as mudanças de comportamento dos alunos após o ingresso na UATI e a frequência nas atividades, os professores apontam que os idosos estão mais comunicativos/extrovertidos (22 professores - 88\%), ampliaram o círculo social, com mais amizades no grupo (18 professores - 72\%) e estão mais questionadores (12 professores $-48 \%$ ).

Os professores também foram questionados se os processos educativos possibilitaram a inserção social do idoso. Todos os professores responderam de forma afirmativa a essa questão. Nas justificativas, emergiram seis conceitos principais: inserção social, segurança, autoestima, participação, valorização e conscientização.

De acordo com 23 professores (92\%), em resposta à outra questão, a participação em atividades da UATI contribui para a conquista de novos papéis sociais na terceira idade. Os outros dois professores afirmam que não possuem subsídios para responder a essa pergunta (8\%). Como explica o professor 3P3: "O papel da UATI é justamente este, contribuir para que os idosos conquistem novos papéis sociais na terceira idade. É muito importante que os professores estimulem atividades que necessitem da participação destes idosos. Devem ser fornecidas opções que mostrem a importância do idoso em contribuir com sua vivência".

A pergunta da sequência solicitava que os professores indicassem como a educação pode contribuir para a atuação política do idoso na sociedade. As respostas foram organizadas a partir de quatro conceitos que emergiram das falas dos professores: espaço de discussão; esclarecimento que leva à participação; consciência dos direitos dos idosos; transformação. Ao considerar as contribuições das UATI para os idosos, os professores foram questionados se o ingresso e a permanência nas ações extensionistas pode proporcionar melhorias significativas para a qualidade de vida dos idosos. Todos os professores responderam positivamente a essa questão - os 25 professores. Na justificativa, tornou-se evidente quatro pontos importantes: educação torna o idoso mais atuante; o idoso se percebe capaz, mais útil; socialização; o idoso aprimorou habilidades e melhorou a autoestima.

A última pergunta do questionário solicitava que os professores apontassem qual é a importância das políticas públicas para a garantia e a efetivação dos direitos dos idosos. De acordo com as respostas dos professores, as políticas públicas precisam de mais discussão e serem amplamente divulgadas, para que os idosos tenham conhecimento e possam usufruir dos direitos nelas contidos. Dentre as políticas, os professores destacam a importância do Estatuto do Idoso. Apontam, ainda, a importância da participação e da conscientização, como meio para que os idosos possam reclamar por melhores condições e que as políticas se efetivem. Conforme explica o professor 1P4: "As políticas públicas têm papel crucial na garantia dos direitos dos idosos. Devem atuar tanto fazendo investimentos em projetos e ação voltados para a terceira idade, quanto garantir que a legislação e as normas que apoiam o idoso sejam respeitadas".

O professor 4P3 complementa explicando que: "As políticas públicas são imprescindíveis no sentido de garantir os direitos da pessoa idosa, porém o estabelecimento de políticas que atendam ao idoso não é suficiente se estas não se transformarem em ações práticas e coesas com as reais necessidades destes. Assim, o exercício do idoso no sentido de empoderamento é de suma importância para que eles exerçam seu papel na sociedade". A partir das considerações sobre as contribuições da política, bem como a influência das UATI para os idosos, percebe-se que os professores, apesar da maioria não possuir uma formação específica para atuar com a terceira idade, tem consciência do contexto social e político em que realizam suas atividades, como também possuem compreensão das particularidades referentes ao ato educativo para o idoso.

Práxis Educativa, Ponta Grossa, v. 14, n. 3, p. 974-996, set./dez. 2019 Disponível em: <http://www.revistas2.uepg.br/index.php/praxiseducativa $>$ 
Assim, as Universidades Abertas para a Terceira Idade representam uma possibilidade de aproximação com a realidade social, política e cultural do envelhecimento e da velhice, uma vez que possibilita que o idoso tenha apropriação de conhecimentos social e historicamente negados, como também propiciam o despertar para sua capacidade de participação e de inserção social, pela qual se percebe em sua condição individual. Além disso, essas ações permitem que o idoso compreenda seu papel de ser social, socialmente integrado, buscando meios para reconhecer a sua alienação, que será consciente de quem é e poderá lutar por sua emancipação, mesmo que seja possível, neste momento, tentar alcançar somente uma emancipação política.

\section{Considerações finais}

A velhice e o envelhecimento no Brasil apontam para grandes contrastes. Se, por um lado, os dados demográficos enaltecem a expressiva quantidade de idosos e a possibilidade de se viver mais; de outro, insurge o receio e o desconforto, inflamado pelo capitalismo, que enxerga e expressa no idoso a representação do desuso, do desgaste e do aumento dos gastos públicos. Diante desse panorama, vivencia-se um processo de marginalização e de preconceito, que gera estereótipos sobre o idoso e a velhice e instaura uma cultura da juventude eterna, em que as pessoas querem viver muito tempo, mas não querem envelhecer. Assim, as políticas para o idoso são emergentes e fundamentais.

Entre as políticas, podem-se citar a Constituição Federal, e mais específicas ao idoso, a Política Nacional do Idoso e o Estatuto do Idoso. Embora haja uma conotação positiva, no que se refere à garantia de direitos, a realidade vivida pelo idoso brasileiro destoa intensamente das prescrições legais. Além disso, tanto as ações do Estado como as políticas são pautadas em princípios ideológicos, as quais se reproduzem de diferentes maneiras, seja pela mídia, cultura, educação que induzem à reprodução e à alienação. E o idoso está inserido nesse contexto.

A alienação está relacionada à atividade produtiva, na qual o sujeito é desapropriado do que produz, tornando-se cada vez mais desumanizado por meio do trabalho, sem valor acaba sendo menosprezado. Assim, a mediação entre o homem e a natureza torna-se vazia; e, desse modo, sujeito e objeto transformam-se em peças do capitalismo. Nesse contexto, a alienação do idoso, por geralmente estar afastado da produção (por exemplo: aposentadoria), é ainda mais complexa, porque esse sujeito não tem mais o objeto como fruto do trabalho e a mediação (homem-natureza), que já era limitada, passa a ser quase nula. $\mathrm{O}$ idoso, pela perda dos diferentes papéis sociais, afasta-se gradualmente do ambiente público e se restringe ao indivíduo privado. Dessa forma, provavelmente será mais profundamente alienado, nas suas diversas formas (política, ideológica, econômica, religiosa, artística e de trabalho). Perante essa realidade contraditória e complexa em que o idoso está inserido, há necessidade de buscar vias para contrapor-se ao sistema, buscando a possibilidade de conscientização e a luta para concretização de direitos, vislumbrando alcançar a emancipação, que, nessa forma de sociedade, poderá ser apenas a política.

A educação, como um meio para propiciar a aquisição de conhecimentos, colabora para que o homem alcance a sua liberdade, pois, ao ter a capacidade de entender o espaço em que está inserido, as relações estabelecidas com o outro, como a sociedade e o Estado intervêm na vida cotidiana, poderá entender melhor quem é. Esses conhecimentos permitem ao sujeito que alcance a fruição e possa estabelecer uma relação distinta entre os demais saberes. Quanto mais o homem se apropria do conhecimento, mais próximo da conscientização ele está; dessa maneira, há uma alternativa que possibilita entender a alienação. O conhecimento não tem a capacidade de liquidar com a alienação, mas pode promover a partir de um concreto pensado uma prática diferenciada. O sujeito não age apenas pelo impulso, mas, ao projetar sua ação, percebe que sua conjuntura é

Práxis Educativa, Ponta Grossa, v. 14, n. 3, p. 974-996, set./dez. 2019 Disponível em: <http://www.revistas2.uepg.br/index.php/praxiseducativa> 
mais ampla do que a sua condição individual e que está imerso pelas condições ideológicas, sociais, políticas, econômicas, culturais e educacionais. Dessa forma, pensar a educação para o segmento idoso não pode ser de outra maneira a não ser pensar na práxis, permitindo que o idoso tenha condições de se reconhecer como idoso, entendendo-se como ser social, o que se dá por meio da atividade produtiva.

A educação para o idoso, pautada nos princípios da educação permanente, necessita considerar a totalidade da ação formativa, reconhecendo as contradições evidenciadas na sociedade do capital. A educação irá cumprir sua função emancipadora ao atuar de maneira consciente, por meio da problematização. Embora uma ação educacional, com princípios emancipatórios, não tenha possibilidades de transformar a realidade e promover a emancipação política, ela tem como alternativa de propiciar conhecimentos, instrumentalizando os sujeitos e levando-os à conscientização (mesmo que parcial).

A partir dos estudos realizados e da pesquisa de campo, constata-se que as Universidades Abertas para a Terceira Idade realizam um trabalho importante no que diz respeito à educação do idoso, fundamentadas na educação permanente, com princípio na educação não-formal. Essas ações, a partir dos relatos de alunos e de professores, a partir do instrumento de coleta de dados, atendem à função educativa, pois promovem ao idoso condições de acesso à informação e ao conhecimento, como também oportunidades de discussão e de possibilidades de aplicar os conhecimentos adquiridos, ultrapassando o limite da teoria.

O processo educativo das UATI, mais do que buscar alcançar o desenvolvimento individual do idoso, provoca mudanças, que geram novos posicionamentos políticos, reflexões sobre o envelhecimento e a velhice, ações críticas, atuação junto à comunidade, problematizações e análise da situação social do idoso. Assim, esta educação que tem liberdade de atuação é organizada a partir das necessidades e não se estabelece sob a vigilância da execução do currículo obrigatório; ela apresenta, portanto, sua perspectiva emancipatória.

A educação promovida pelas UATI almeja um processo de conscientização e busca, na atuação dos professores e integração dos alunos, apresentar quais são as formas de alienação, visando um processo de emancipação política, o qual ainda não se materializou. Dentre as limitações existentes nas UATI para que a emancipação se efetive, destaca-se a forma de atuação dos professores, que, por vezes, ainda é realizada a partir das experiências da educação formal, o que representa a necessidade da formação dos professores.

Embora as UATI realizem ações para promover as relações intergeracionais entre os idosos e a comunidade acadêmica, as discussões sobre o envelhecimento e a velhice são limitadas e ocorrem em poucas situações, não estando no cotidiano das universidades, inclusive ausente nos currículos dos cursos de Graduação, quando diz respeito aos aspectos sociais e gerontológicos.

Devido à ausência de recursos públicos, embora as ações analisadas estejam em universidades públicas, há limitações para ampliação de vagas, o que impõe mais uma dificuldade às UATI, que, apesar de atender a uma quantidade importante de idosos, ainda são restritas a poucas cidades. Outro fator de impacto é o desinteresse da comunidade universitária, que também reflete em dificuldades às ações extensionistas. Ainda há limitação de produções acadêmicas sobre a Universidade Aberta para a Terceira Idade, que não se restrinjam à reprodução de dados e à divulgação de experiências. Há uma grande demanda de pesquisas sobre as UATI, com problematizações sobre a educação e as possibilidades de conscientização e de emancipação. 
A educação não irá emancipar ninguém, mas pode promover o despertar às contradições da realidade do sistema capitalista em que os idosos estão inseridos e colaborar para que a práxis se materialize. Dessa forma, uma mudança, mesmo que pequena, é necessária e possível.

\section{Referências}

AMBROSINI, T. F. Educação e emancipação humana: uma fundamentação filosófica. Revista HISTEDBR On-line, Campinas, v. 12, n. 47, p. 378-391, set. 2012. DOI: https://doi.org/10.20396/rho.v12i47.8640058

BRASIL. [Constituição (1988)]. Constituição da República Federativa do Brasil. Brasília, DF: Senado, 1988.

BRASIL. Lei no .8842 de 4 de janeiro de 1994. Dispõe sobre a Política Nacional do Idoso. Diário Oficial da União, Brasília, 5 jan. 1994.

BRASIL. Lei no 10.741 de 3 de outubro de 2003. Dispõe sobre o Estatuto do Idoso e dá outras providências. Diário Oficial da União, Brasília, 3 out. 2003.

CACHIONI, M. et al. Metodologias e estratégias pedagógicas utilizadas por educadores de uma Universidade Aberta à Terceira Idade. Educação \& Realidade, Porto Alegre, v. 40, n. 1, p. 81 103, jan./mar. 2015. DOI: http://dx.doi.org/10.1590/2175-623645741

FERNANDES, A. A. Velhice e sociedade. Oeiras: Celta, 1997.

FREIRE, P. Educação e mudança. 30. ed. Rio de Janeiro: Paz e Terra, 2007.

GIUDICI, E. Alienación, marxismo y trabajo intelectual. Buenos Aires: Crisis, 1973.

IBGE. Projeção da população por sexo e idade para o período 2000 - 2060. Diretoria de Pesquisas. Coordenação de População e Indicadores Sociais. Revisão 2013, Rio de Janeiro: Fundação Instituto Brasileiro de Geografia e Estatística, 2013.

KONDER, L. Marxismo e alienação: contribuição para um estudo do conceito marxista de alienação. 2. ed. São Paulo: Expressão Popular, 2009.

KONDER, L. O que é dialética. 28. ed. São Paulo: Brasiliense, 2012.

MARX, K. Contribuição à crítica da economia política. 2. ed. São Paulo: Expressão Popular, 2008.

MARX, K. Para a questão judaica. São Paulo: Expressão Popular, 2009.

MÉSZÁROS, I. A teoria da alienação em Marx. Tradução de Isa Tavares. São Paulo: Boitempo, 2006.

MÉSZÁROS, I. La educación más allá del capital. Buenos Aires: Siglo Veintiuno, 2008. 
OLIVEIRA, R. C. S. Terceira idade: do repensar dos limites aos sonhos possíveis. Campinas: Papirus, 1999.

OLIVEIRA, R. C. S. Universidade Aberta para a Terceira Idade na Universidade Estadual de Ponta Grossa. 1998. 635 f. Tese (Doutorado em Filosofia e Ciências da Educação) Universidade de Santiago de Compostela, Santiago de Compostela, 1998.

PINTO, A. V. Sete lições sobre educação de adultos. 16. ed. São Paulo: Cortez, 2010.

TONET, I. Educação, cidadania e emancipação humana. 2. ed. Maceió: Edufal, 2013.

Recebido em 07/05/2019

Versão corrigida recebida em 14/08/2019

Aceito em 16/08/2019

Publicado online em 23/08/2019 